Original Article

\title{
THE EFFECTS OF AGE OF GRAFTED LARVAE AND OF SUPPLEMENTAL FEEDING ON PERFORMANCE OF IRANIAN HONEY BEE COLONIES (APIS MELLIFERA MEDA)
}

\author{
Ali Mahbobi ${ }^{1}$ \\ Jerzy Woyke ${ }^{2 *}$ \\ Saeed Abbasi ${ }^{3}$ \\ Mohammadbagher Farshineh-Adl ${ }^{4}$ \\ Ahmad Malakzadegan ${ }^{5}$
}

'Department of Animal Science, University of Zanjan, Zanjan, Iran

2Apiculture Division, University of Life Sciences, Warsaw, Poland

3Department of Animal Science, University of Tehran, Karaj, Iran

${ }^{4}$ Animal Science Research Institute, Karaj, Iran

${ }^{5}$ Department of Animal Science, Ferdowsi University of Mashhad, Mashhad, Iran

*corresponding author: jerzy_woyke@sggw.pl

Received 02 August 2013; accepted 13 February 2014

\begin{abstract}
A b s tract
The performance of bee colonies greatly depends on the quality of the queens. The current research was conducted at the apiary of the Faculty of Agriculture, Zanjan University, in Zanjan, Iran. Together, 24 rearing colonies were assigned to 4 grafting larvae age groups: 1-day-old, 2-day-old, 3-day-old, and emergency queens. Two feeding groups, fed and not fed, were created. The effects of reared queens on biological characteristics and performance of honeybee colonies (Apis mellifera meda) headed by those queens were measured. Age of grafted larvae significantly influenced the results. The performance ratios of the most efficient colonies headed by queens reared from 1-day-old larvae compared with the least-efficient queens reared from 3-day-old larvae were $118 \%$ in brood production, $140 \%$ in bee population, and $154 \%$ in honey production. However, the age of grafted larvae did not affect colony defense behavior. Supplemental feeding of rearing colonies increased brood production to $111 \%$, bee population to $116 \%$, and honey production to $115 \%$. A combination of the effect of age of larvae and supplemental feeding resulted in twice as much honey $(12 \mathrm{~kg})$ produced by colonies with queens reared from 1-day-old larvae in fed rearing colonies compared to those with queens raised from 3-day-old larvae in unfed rearing colonies.
\end{abstract}

Keywords: Apis mellifera meda, grafting larvae, honey bee queen, honey yield, Iranian honey bee, supplemental feeding.

\section{INTRODUCTION}

Queen quality is an important influence not only on brood production but also on colony productivity (Ruttner, 1983; Laidlaw and Page, 1992). Racial and environmental aspects are the fundamental factors affecting the reproductive features of the queen honeybee. The main environmental factors determining the quality of a queen are season, climate, food supply, age of grafted larvae, and condition of rearing colonies (Woyke, 1971). The characteristics of honeybee colonies are determined by the queen and her fecundating drones.
Colonies with a young queen have been reported to have a greater population and produce 27 - 30\% more honey than colonies with old queens (Woyke, 1984). The reproductive potential of a queen is inversely proportional to the age of the larvae from which she was reared. Woyke (1971) raised queens from eggs and young larvae, which developed normally, whereas queens reared from 3-day-old larvae, were reduced in size and number of ovarioles. Therefore, selection could be acting on colonies to rear more fecund queens by raising them from the youngest possible brood source. We conducted this experiment to determine the effects of the age of 
grafted larvae and supplemental feeding of rearing colonies on the performance of colonies (brood production, adult bee population, aggressiveness behavior, and honey yield) headed by those honey bee queens under normal beekeeping conditions in Iran.

\section{MATERIAL AND METHODS}

This research was conducted in May and September 2007 at the apiary of the Agriculture faculty of Zanjan University in Zanjan, Iran. First, an Iranian breeder colony (Apis mellifera meda) was selected from breeder stock in the apiary by evaluating colony records. The queen of the breeder colony was confined on 3 empty combs by perpendicular queen excluders (Büchler et al., 2013). The confinement was done to provide larvae of known age for grafting purposes.

We selected 24 Iranian honey bee-rearing colonies of the same strength, headed by 1-year-old queens. The colonies were made queenless and next were randomly assigned to 4 groups by grafting larvae age: 1-, 2-, and 3-day old larvae and emergency queen cells (Ruttner, 1983; Laidlaw and Page, 1992). All then were subdivided into 2 feeding groups, fed and not fed. Thus, $4 \times 2=8$ combination groups were created. Each combination was repeated in 3 colonies for a total of 24 rearing colonies. The colonies were fed with pollen supplement (sugar powder, milk powder and honey, $2: 2$ and 1 respectively) 3 weeks before grafting, which was continued until the queen cells were sealed.

One day before emergence of the virgin queens, mature queen cells in each starter-finisher colony were transferred to 24 newly established colonies. After 50 days, we measured the following 4 traits: brood production, adult bee population, defense behavior, and honey yield. Thus, all together, 96 measurements were conducted.

\section{Brood production}

The brood production was measured with one prototype frame divided into $5 \times 5 \mathrm{~cm}^{2}$ compartments. By laying this frame onto the brood combs of each colony, the total brood surface was recorded for trial colonies.

\section{Adult bee population}

The adult worker bee population was visually determined by estimation of the number of combs covered by bees in each colony. Combs that were completely covered on 2 sides by adult bees were considered as 1 comb while the less populous combs were expressed as a proportion of 1 (Delaplane et al., 2013).

\section{Defensive behavior}

The defensive behavior of honeybee colonies (A. m. meda) was tested with a black leather ball that was moved $50 \mathrm{~cm}$ in front of the hive entrance for 1 minute. Next the stings left in the ball were counted (Woyke, 1992).

\section{Honey yield}

Honey yield was measured by weighing the boxes with honey as they were removed from hives and then subtracting the weight of empty boxes after the honey was extracted (Woyke, 1984).

\section{Statistical analyses}

Two-factor ANOVA was used to determine the effect of larval age and feeding on performance of honeybee colonies. Duncan's multiple comparison tests were applied to compare the means $(p<0.05)$. SAS software version 8.2 was used to perform statistical calculations.

\section{RESULTS}

\section{Brood production}

Two-factor ANOVA showed that the brood area was significantly affected by the age of the larvae $\left(F_{3,16}=190.05, p<0.0001\right)$, as well as by feeding $\left(F_{1,16}^{3,16}=424.18, p<0.0001\right)$. The interaction between the two factors was not found to be significant $\left(F_{3,16}=2.77, p=0.0805\right)$.

Table 1 shows that brood production in colonies headed by queens reared from 1-day-old larvae was significantly the highest $\left(3012.6 \mathrm{~cm}^{2}\right)$. The lowest brood production was in colonies with queens from 3-day-old larvae $\left(2553.1 \mathrm{~cm}^{2}\right)$. Brood production in colonies with queens from emergency queen cells was intermediate $\left(2710.6 \mathrm{~cm}^{2}\right)$. The highest brood production was $118 \%$ of the lowest.

The brood area was significantly higher in colonies with queens reared in fed queenless colonies $\left(2887.9 \mathrm{~cm}^{2}, 111 \%\right)$ than in the unfed ones (2599.5 cm², 100\%).

\section{Adult bee population}

Two-factor ANOVA showed that the bee population was significantly affected by the age of the larvae $\left(F_{3,16}=82.33, p<0.0001\right)$, as well as by feeding $\left(F_{1,16}^{3,16}=84.64, p<0.0001\right)$. The interaction between the two factors was not found to be significant $\left(F_{3,16}=2.77, p=0.077\right)$.

Table 2 shows that the bee population in colonies headed by queens reared from 1-day-old larvae was significantly the highest (8 combs, 140\%). Colonies with queens reared from 3-day-old larvae (5.7 combs, $100 \%$ ) had significantly the lowest population. 


\section{J. APIC. SCLI. VOL. 58 N NO. 12014}

Brood production $\left(\mathrm{cm}^{2}\right)$ in 24 colonies with queens reared

Table 1. from larvae of different ages and fed different

\begin{tabular}{cccc}
\hline $\begin{array}{c}\text { Age of } \\
\text { larvae days }\end{array}$ & $\begin{array}{c}\text { Feeding } \\
\text { Mean } \pm \text { SD }(n=3)\end{array}$ & $\begin{array}{c}\text { No feeding } \\
\text { Mean } \pm \text { SD }(n=3)\end{array}$ & $\begin{array}{c}\text { Overall } \\
\text { Mean } \pm \text { SD }(n=6)\end{array}$ \\
\hline 1 & $3183.1 \pm 31.8$ & $2842.0 \pm 2.2$ & $3012.6 \pm 44.5$ a \\
\hline 2 & $2838.9 \pm 5.6$ & $2558.2 \pm 22.9$ & $2698.6 \pm 36.3$ b \\
\hline 3 & $2667.8 \pm 15.4$ & $2438.4 \pm 7.6$ & $2553.1 \pm 30.0$ c \\
\hline Emergency & $2861.7 \pm 27.1$ & $2559.5 \pm 35.6$ & $2710.6 \pm 40.0$ b \\
\hline Overall $(n=12)$ & $2887.9 \pm 33.1$ a & $2599.5 \pm 26.9$ b & \\
\hline ans with the same letter are not significantly different $(p<0.05)$ in the same column or line.
\end{tabular}

Adult bee population (combs) in colonies with queens reared

Table 2. from larvae of different age and fed differently

\begin{tabular}{cccc}
\hline $\begin{array}{c}\text { Age of } \\
\text { larvae days }\end{array}$ & $\begin{array}{c}\text { Feeding } \\
\text { Mean } \pm \operatorname{SD}(\mathrm{n}=3)\end{array}$ & $\begin{array}{c}\text { No feeding } \\
\text { Mean } \pm \mathrm{SD}(\mathrm{n}=3)\end{array}$ & $\begin{array}{c}\text { Overall } \\
\text { Mean } \pm \mathrm{SD}(\mathrm{n}=\mathbf{6})\end{array}$ \\
\hline 1 & $8.7 \pm 0.1$ & $7.3 \pm 0.1$ & $8.0 \pm 0.2 \mathbf{a}$ \\
\hline 2 & $6.9 \pm 0.1$ & $6.1 \pm 0.2$ & $6.5 \pm 0.1 \mathbf{b}$ \\
\hline 3 & $6.2 \pm 0.2$ & $5.2 \pm 0.1$ & $5.7 \pm 0.2 \mathbf{c}$ \\
\hline Emergency & $6.9 \pm 0.0$ & $6.2 \pm 0.1$ & $6.5 \pm 0.1 \mathbf{b}$ \\
\hline
\end{tabular}

Overall $(n=12) \quad 7.2 \pm 0.2$ a $\quad 6.2 \pm 0.1 \mathrm{~b}$

Means with the same letter are not significantly different $(p<0.05)$ in the same column or line.

Table 3.

Defensive behavior (no. of stings) in colonies with queens reared from larvae of different ages and fed differently

\begin{tabular}{cccc}
\hline $\begin{array}{c}\text { Age of } \\
\text { larvae days }\end{array}$ & $\begin{array}{c}\text { Feeding } \\
\text { Mean } \pm \operatorname{SD}(n=3)\end{array}$ & $\begin{array}{c}\text { No feeding } \\
\text { Mean } \pm \operatorname{SD}(\mathrm{n}=3)\end{array}$ & $\begin{array}{c}\text { Overall } \\
\text { Mean } \pm \operatorname{SD}(\mathrm{n}=6)\end{array}$ \\
\hline 1 & $11.0 \pm 7.3$ & $4.4 \pm 2.00$ & $7.7 \pm 3.7 \mathrm{a}$ \\
\hline 2 & $6.2 \pm 2.9$ & $6.6 \pm 1.33$ & $6.6 \pm 1.4 \mathrm{a}$ \\
\hline 3 & $4.1 \pm 0.1$ & $7.4 \pm 4.3$ & $5.8 \pm 2.1 \mathrm{a}$ \\
\hline Emergency & $6.7 \pm 1.7$ & $8.1 \pm 3.5$ & $7.4 \pm 1.8 \mathrm{a}$ \\
\hline Overall $(\mathrm{n}=12)$ & $7.01 \pm 1.9$ a & $6.67 \pm 1.4$ a & \\
\hline Means with the same letter are not significantly different $(p<0.05)$ in the same column or line.
\end{tabular}

The bee population was significantly higher (7.2 combs, $116 \%$ ) in colonies with queens reared in fed queenless colonies (7.2 combs, $116 \%$ ) than with queens reared in unfed ones (6.2 combs, 100\%).

\section{Defensive behavior}

Two-factor ANOVA showed that the defensive behavior was not found to be significantly affected neither by the age of the larvae $\left(F_{3,16}=0.14\right.$, $p=0.934)$ nor by feeding $\left(F_{1,16}=0.02, p=0.887\right)$. The interaction between the two factors also was not found to be significant $\left(F_{3,16}=0.83, p=0.50\right)$.
Neither the age of grafted larvae nor the feeding of rearing colonies affected defense behavior of colonies headed by the queens.

\section{Honey yield}

Two-factor ANOVA showed that the honey yield was significantly affected by the age of the larvae $\left(F_{3,16}=29.38, p<0.0001\right)$, as well as by feeding $\left(F_{1,16}=15.63, p=0.0014\right)$. The interaction between the two factors was not found to be significant $\left(F_{3,16}=1.46, p=0.26\right)$. 
Table 4.

Honey yield $(\mathrm{kg})$ in colonies with queens reared from larvae of different ages and fed differently

\begin{tabular}{cccc}
\hline $\begin{array}{c}\text { Age of } \\
\text { larvae days }\end{array}$ & $\begin{array}{c}\text { Feeding } \\
\text { Mean } \pm \text { SD }(n=3)\end{array}$ & $\begin{array}{c}\text { No feeding } \\
\text { Mean } \pm \text { SD }(n=3)\end{array}$ & $\begin{array}{c}\text { Overall } \\
\text { Mean } \pm \text { SD }(n=6)\end{array}$ \\
\hline 1 & $12.0 \pm 0.5 \mathbf{A}$ & $9.9 \pm 1.0 \mathbf{B}$ & $11.0 \pm 0.7 \mathbf{a}$ \\
\hline 2 & $9.5 \pm 0.4 \mathrm{BC}$ & $8.5 \pm 0.4 \mathrm{BC}$ & $9.0 \pm 0.4 \mathbf{b}$ \\
\hline 3 & $7.7 \pm 0.3 \mathbf{C D}$ & $6.3 \pm 0.6 \mathbf{E}$ & $7.0 \pm 0.4 \mathbf{c}$ \\
\hline Emergency & $8.5 \pm 0.7 \mathrm{DC}$ & $8.2 \pm 0.5 \mathrm{~B} \mathrm{CD}$ & $8.3 \pm 0.4 \mathbf{b}$ \\
\hline Overall $(\mathrm{n}=12)$ & $9.4 \pm 0.5 \mathbf{a}$ & $8.2 \pm 0.5 \mathbf{b}$ & \\
\hline
\end{tabular}

Means with the same letter are not significantly different ( $p<0.05)$. Capitals concern all 8 means and lower-case letters concern overalls in the same column or the same line.

Table 4 shows that the honey yield in colonies headed by queens reared from 1-day-old larvae was significantly the highest (11 kg, 154\%). Significantly the lowest honey yield was in colonies with queens from 3-day-old larvae (7 kg, 100\%). Colonies with emergency queens produced significantly more honey $(8.3 \mathrm{~kg}$ ) than those headed by queens reared from 3-day-old larvae $(7.0 \mathrm{~kg})$.

The honey yield in colonies with queens reared in fed queenless colonies was significantly higher $(9.4 \mathrm{~kg}$, $115 \%)$ than in those headed by queens reared in unfed colonies ( $8.2 \mathrm{~kg}, 100 \%)$.

Detailed comparison of the effect of the 8 combinations ( 4 ages $\times 2$ feeding protocols) on honey production showed that significantly the lowest amount of honey $(6 \mathrm{~kg})$ was harvested from colonies headed by queens reared from 3-day-old larvae in unfed rearing colonies. Significantly the highest amount $(12 \mathrm{~kg})$ was harvested from colonies with queens reared from 1-day-old larvae in fed rearing colonies. Thus, colonies with the best queens produced twice as much honey as those with the worst queens.

\section{DISCUSSION}

We found that the age of grafted larvae ( 1 - 3 days old and emergence) significantly affected the reared queens that headed the test colonies. Colonies headed by queens reared from 1-day-old larvae were the most efficient while those headed by queens reared from 3-day-old larvae were the least efficient. The performance of the most efficient colonies was, as a ratio to the least efficient, $118 \%$ in brood production, $140 \%$ in bee population, and $154 \%$ in honey production. However, the age of grafted larvae did not affect the defense behavior of colonies headed by those queens.
Earlier publications have reported primarily the effect of the age of grafted larvae on morphological characters of reared queens; see, e.g., an overview by Mahbobi et al. (2012). Woyke (1971) showed that queens reared from younger larvae are heavier and have more ovarioles in the ovaries and more spermatozoa in the spermatheca after natural or instrumental insemination. Thus, they are expected to produce colonies of higher performance. According to Nelson and Gary (1983), honey production is correlated positively with queen weight. Colony strength of honey bees has been found to be one of the most important factors for maximizing honey production (Neupane et al., 2012). Weiss $(1971,1983)$ found no difference in honey production by colonies headed by queens reared from eggs or 1.5-day-old larvae. We identified no publications comparing the performance of colonies headed by queens reared from larvae 1 - 3 days old. Our results showed that the performance of colonies headed by queens reared from younger larvae is superior.

In addition, we found that colonies headed by queens raised in fed rearing colonies increased brood production up to $111 \%$, bee population to $116 \%$, and honey production to $115 \%$, relative to colonies with queens reared in unfed colonies.

In contrast to the opinion of many beekeepers, Weiss (1983, p. 139) found no correlation between stimulating feeding of rearing colonies and the results of queen rearing. Additional feeding may be necessary during a dearth period. Mahbobi et al. (2012) showed that queens reared in fed colonies were significantly heavier $(160 \mathrm{mg})$ than those reared in unfed ones (145 mg). Thus, the heavier queens reared in fed rearing colonies are expected to create more productive bee colonies, as noted above. Unfortunately, we could not identify any publication recording the direct effect of additional feeding of 
rearing colonies on the performance of colonies headed by such queens.

We found that the combination of the two factors of grafted larvae age and feeding of rearing colonies was very efficient. Colonies headed by queens raised from larvae 1 day old in fed rearing colonies produced twice as much honey $(12 \mathrm{~kg})$ as colonies with queens raised from 3-day-old larvae in unfed colonies (6 kg).

We could not locate publications reporting the direct effect of the age of grafted larvae ( 1 - 3 days old) and of additional feeding of rearing colonies on the performance of colonies headed by such queens. Our work may be the first to record the direct effect of the age of grafted larvae ( 1 - 3 days old) and additional feeding of rearing colonies on the performance of colonies headed by queens reared in those conditions.

\section{CONCLUSIONS}

The performance of colonies headed by queens reared from larvae 1 - 3 days old and from emergency queen cells is the highest in colonies with queens raised from larvae 1 day old.

The performance of colonies with queens raised in fed rearing colonies is higher than that with queens raised in unfed colonies.

Colonies headed by queens rose from 1-day-old larvae in fed rearing colonies produce twice as much honey as those with queens raised from 3-day-old larvae in unfed colonies.

\section{REFERENCES}

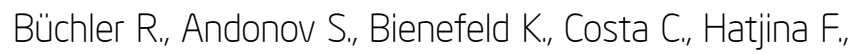
Kezic N., Kryger P., Spivak M., Uzunov A., Wilde J. (2013) Standard methods for rearing and selection of Apis mellifera queens. In: Dietemann V., Ellis J. D., Neumann P. (Eds) The COLOSS BEEBOOK, Volume l: standard methods for Apis mellifera research. Journal of Apicultural Research 52(1): 1-29. DOl: 10.3896/IBRA. 1.52.1.07

Delaplane K. S., Van der Steen J., Guzman E. (2013) Standard methods for estimating strength parameters of Apis mellifera colonies. In: Dietemann V., Ellis J. D., Neumann P. (Eds) The COLOSS BEEBOOK, Volume l: standard methods for Apis mellifera research. Journal of Apicultural Research. 52(1): 1-12. DOl: 10.3896/IBRA.1.52.1.03
Laidlaw H. H., Page R. E. (1 997) Queen rearing and bee breeding. Wicwas Press. Connecticut, USA. 224 pp.

Mahbobi A., Farshineh-Adl M. B., Woyke J., Abbasi S. (2012) Effects of age of grafted larvae and supplemental feeding on some morphological characteristics of Iranian queen honey bees (Apis mellifera meda Skorikov, 1929). Journal of Apicultural Science 56 (1): 93-98.

Nelson D., Gary N. (1983) Honey productivity of honeybee colonies in relation to body weight, attractiveness and fecundity of the queen. Journal of Apicultural Research 22(4): 209-213.

Neupane K. R., Woyke J., Wilde J. (2012) Effect of initial strength of honey bee colonies (Apis mellifera) supered in different ways on maximizing honey production in $\mathrm{Ne}$ pal. Journal of Apicultural Science 56(2): 71-81.

Ruttner F. (1983) Queen rearing, biological basis and technical instruction. Apimondia Publ. House. Bucharest. 358 pp.

Weiss K. (1971) Über Ausbildung und Leistung von Königinnen aus Eiern und jungen Arbeitermaden. Apidologie $2(1): 3-47$.

Weiss K. (1983) Age of graft and performance of the colony. In: F. Ruttner (Ed) Queen rearing. Apimondia Pub. House. Bucharest: 90-93.

Woyke J. (1971) Correlations between the age at which honeybee brood was grafted, characteristics of the resultant queens, and results of insemination. Journal of Apicultural Research 10(1): 45-55.

Woyke J. (1984) Correlations and interactions between population, length of worker life and honey production by honeybees in temperate region. Journal of Apicultural Research 23(3): 148-154.

Woyke J. (1992) Diurnal and seasonal variation in defensive behavior of African bees Apis mellifera adansonii in Ghana. Apidologie 23(4): 31 1-322. 